\title{
Estimasi Curah Hujan Bulanan Kota Pontianak Dengan Suhu Permukaan Laut Sebagai Estimator Berdasarkan Jaringan Syaraf Tiruan Backpropagation
}

\author{
Herkulana F ${ }^{1)}$, Andi Ihwan ${ }^{1)}$, M. Ishak Jumarang ${ }^{1)}$
}

\author{
1Program Studi Fisika Fakultas Matematika dan pengetahuan Alam \\ Universitas Tanjungpura. \\ Email : herkulanastarla@gmail.com
}

\begin{abstract}
Abstrak
Telah dilakukan estimasi untuk mengetahui pengaruh Suhu Permukaan Laut (SPL) terhadap curah hujan bulanan wilayah kota Pontianak tahun 2001 s.d 2012 menggunakan Jaringan Syaraf Tiruan (JST) algoritma Backpropagation. Pada penelitian ini Backpropagation dibangkitkan dengan arsitektur [15 105 1]. Terdapat 16 titik SPL dari 24 titik pengamatan yang dijadikan sebagai fokus pengamatan. Dari hasil simulasi diperoleh bahwa pada proses training koefisien korelasi antara output dan target berkisar dari 0,99 s.d 1,00 sedangkan pada proses testing diperoleh 3 koefisien korelasi tertinggi yaitu 0,70; 0,71 dan 0,75, yang masing-masing berada disekitar garis equator. 2 wilayah di perairan Samudera Hindia dan 1 di wilayah Samudera Pasifik. Koefisien Korelasi ini menunjukkan bahwa pola SPL mendekati pola curah hujan di Pontianak (pola equatorial).
\end{abstract}

Kata kunci: suhu permukaan laut, backpropagation, curah hujan.

\section{Pendahuluan}

Hujan merupakan bentuk presipitasi yang jatuh ke bumi dalam bentuk cair. Terjadinya hujan sangat berhubungan dengan beberapa parameter iklim, diantaranya lamanya penyinaran matahari, suhu udara, kelembaban udara, awan, angin, dan tekanan udara. Selain parameter tersebut di atas, hujan juga sangat dipengaruhi oleh suhu permukaan laut (SPL).

Metode yang dapat digunakan untuk menangani data dalam jumlah besar salah satunya adalah metode jaringan syaraf tiruan (JST). Metode ini memiliki kelebihan yang menjadi nilai tambah untuk digunakan, yaitu kemampuan metode ini untuk melakukan proses pembelajaran. Dalam penelitian ini akan dikaji tentang korelasi antara curah hujan dengan suhu permukaan laut serta untuk mengestimasi tingkat curah hujan pada waktu yang akan datang.

\section{Landasan Teori}

\subsection{Fenomena Iklim Indonesia}

Pola hujan di Indonesia dapat dibedakan menjadi tiga tipe yakni tipe equatorial, tipe monsun dan tipe lokal (Tukidi, 2010).

SPL merupakan indikator penting yang mempengaruhi curah hujan. Salah satu fenomena yang menunjukkan adanya perubahan SPL yang kemudian berpengaruh terhadap curah hujan di Indonesia yaitu fenomena yang terjadi di Samudera Hindia yang disebut dengan Dipole Mode (DM) yang merupakan fenomena couple antara atmosfer dan lautan yang ditandai dengan perbedaan anomali dua kutub SPL di samudera Hindia tropis bagian tengah sampai barat. SPL juga dipengaruhi oleh fenomena El Nino Southern
Oscillation (ENSO) di wilayah perairan Samudera Pasifik. SPL tidak berada pada posisi yang sama sehingga dapat berubah pada waktu tertentu (Djunarsjah, 2005).

\subsection{Jaringan Syaraf Tiruan Algoritma Backpropagation}

Menurut Siang (2004) JST merupakan suatu sistem jaringan pemroses informasi dengan karakteristik yang menyerupai jaringan syaraf biologi. Karena meniru system syaraf biologis maka terdapat tiga karakteristik utama dari JST yakni arsitektur jaringan, algoritma jaringan dan fungsi aktifasi (Desiani dan Arhami, 2005).

\section{Metodologi}

Sistem yang dibuat akan melalui beberapa tahap sebagai berikut:

1. Pengelompokan data

Data yang digunakan dalam penelitian ini merupakan data SPL pada batasan lintang $20 \mathrm{~N}-20 \mathrm{~S}$ dan bujur $30 \mathrm{E}-180 \mathrm{E}$ pada tahun 2001 s.d 2012 (sumber: www.emcwf.int) dan data curah hujan di kota Pontianak pada tahun 2001 s.d 2012 (sumber: stasiun BMKG Supadio Pontianak). Data dikelompokan menjadi 2 bagian, yaitu data training dan data testing, dimana masing-masing kelompok data terdiri dari data input dan data target.

2. Perancangan arsitektur JST

Arsitektur JST dibuat dengan menentukan banyaknya input layer, hidden layer, dan output layer yang akan digunakan dalam training. JST terdiri dari 4 neuron yang mana masing-masing mewakili input data SPL ke-(T-36), (T-24), (T-12) dan (T). Data 
curah hujan digunakan sebagai target. Hidden layer pertama terdiri dari 15 neuron dengan fungsi aktivasi Tansig, hidden layer kedua terdiri dari 10 neuron dengan fungsi aktivasi logsig dan hidden layer terakhir terdiri dari 5 neuron dengan fungsi aktivasi logsig. Untuk output layer terdapat 1 neuron dengan fungsi aktivasi purelin.

3. Training dan Testing pada JST.

a. Training JST (tahun 2001 s.d 2008) merupakan proses pengenalan pola data. Training JST dilakukan dengan menyesuaikan nilai-nilai bobot yang ditetapkan diawal training supaya menghasilkan jaringan terlatih (net). Kondisi penghentian training apabila tercapainya nilai Mean Square Error (MSE) di akhir training. Training dihentikan apabila nilai MSE di akhir training kurang dari atau mendekati atau sama dengan nilai MSE yang ditetapkan pada awal training. Tetapi apabila nilai MSE di akhir training lebih besar dari nilai MSE yang ditetapkan di awal training, maka proses training akan dilanjutkan ke tahap backpropagation.

b. Testing (tahun 2009 s.d 2012) dilakukan dengan memberikan input berupa sebagian dari data yang tidak diikutsertakan dalam proses training. Sebagai pembanding pada proses validasi, digunakan target pada data observasi.

4. Validasi

Validasi data dilakukan dengan menggunakan data curah hujan dan SPL pada tahun 2009 s.d 2012. Jika koefisien korelasi (R) antara data training dengan data testing $\geq 0.6$ maka model tersebut dapat mewakili curah hujan yang ada di daerah tersebut.

\section{Hasil dan Diskusi}

Tahapan yang dilakukan dalam penelitian ini yaitu tahap permodelan (training dan testing) serta tahap validasi.

a. Proses training pada Jaringan Syaraf Tiruan (JST)

Tujuan training pada JST adalah untuk mengenali pola SPL sebagai input dan curah hujan sebagai target. Data SPL dan curah hujan tersebut pada JST dimasukan pada input layer, kemudian data pada input layer tersebut dipropagasi maju ke hidden layer. Fungsi hidden layer adalah meneruskan sinyal dari input layer sehingga menghasilkan output pada JST.

Banyaknya hidden layer yang digunakan pada penelitian ini sebanyak 3 hidden layer. Nilai pembobotan pada hidden layer menggunakan nilai acak (random) dengan batasan dari -0,5 s.d 0,5 . Pemberian batas yang sangat kecil ini dimaksudkan agar tidak terjadi pembobotan yang terlalu besar sehingga dengan rentangan nilai yang sangat kecil ini dapat menghasilkan nilai keluaran yang bagus dan cenderung stabil. Pada tahap training ini juga digunakan modifikasi JST dengan menambahkan momentum. Perubahan momentum ini dimaksudkan untuk menghindari perubahan bobot yang mencolok akibat adanya data yang sangat berbeda dengan data yang lainnya. Fungsi momentum adalah untuk perbaikan bobot.

Setelah proses propagasi maju dilakukan, akan diperoleh nilai output yang diinginkan. Jika output tersebut tidak sesuai dengan MSE sebesar $10^{-3}$ maka jaringan syaraf tiruan akan melakukan tahapan backpropagation.

Pada penelitian ini training dilakukan di 24 wilayah data suhu permukaan laut. Dari 24 wilayah hanya 16 wilayah yang digunakan karena 8 wilayah lainnya merupakan daratan. Dari 16 wilayah tersebut akan dicari wilayah yang SPL nya sesuai dengan pola curah hujan di kota Pontianak.

Tabel 1. Hasil Proses Training

\begin{tabular}{cccc}
\hline No & $\begin{array}{c}\text { Koordinat } \\
\text { (Bujur; Lintang) }\end{array}$ & $\mathrm{R}$ & MSE \\
\hline 1 & $63 ; 19,5$ & 1 & $2,97 \mathrm{e}-06$ \\
2 & $117 ; 19,5$ & 1 & $9,68 \mathrm{e}-06$ \\
3 & $135 ; 19,5$ & 1 & $1,26 \mathrm{e}-13$ \\
4 & $153 ; 19,5$ & 1 & $8,74 \mathrm{e}-07$ \\
5 & $171 ; 19,5$ & 0,99 & $3,11 \mathrm{e}-04$ \\
6 & $45 ; 1,5$ & 0,99 & $2,93 \mathrm{e}-04$ \\
7 & $63 ; 1,5$ & 1 & $1,33 \mathrm{e}-04$ \\
8 & $81 ; 1,5$ & 1 & $4,46 \mathrm{e}-06$ \\
9 & $153 ; 1,5$ & 1 & $6,03 \mathrm{e}-05$ \\
10 & $171 ; 1,5$ & 0,99 & $3,14 \mathrm{e}-04$ \\
11 & $63 ;-16,5$ & 1 & $2,97 \mathrm{e}-06$ \\
12 & $81 ;-16,5$ & 1 & $1,90 \mathrm{e}-09$ \\
13 & $99 ;-16,5$ & 1 & $9,72 \mathrm{e}-07$ \\
14 & $117 ;-16,5$ & 1 & $3,29 \mathrm{e}-06$ \\
15 & $153 ;-16,5$ & 0,99 & $1,75 \mathrm{e}-04$ \\
16 & $171 ;-16,5$ & 1 & $1,72 \mathrm{e}-09$ \\
\hline
\end{tabular}

Pada keseluruhan hasil training (Tabel.1) nilai MSE terkecil sebesar $1,26 \mathrm{e}^{-13}$ dan nilai MSE terbesar sebesar 3,14e-04. Perbedaan nilai MSE ini terjadi karena pada saat proses training berjalan nilai MSE belum mencapai target yang diinginkan, sedangkan iterasi sudah mencapai maksimum. 

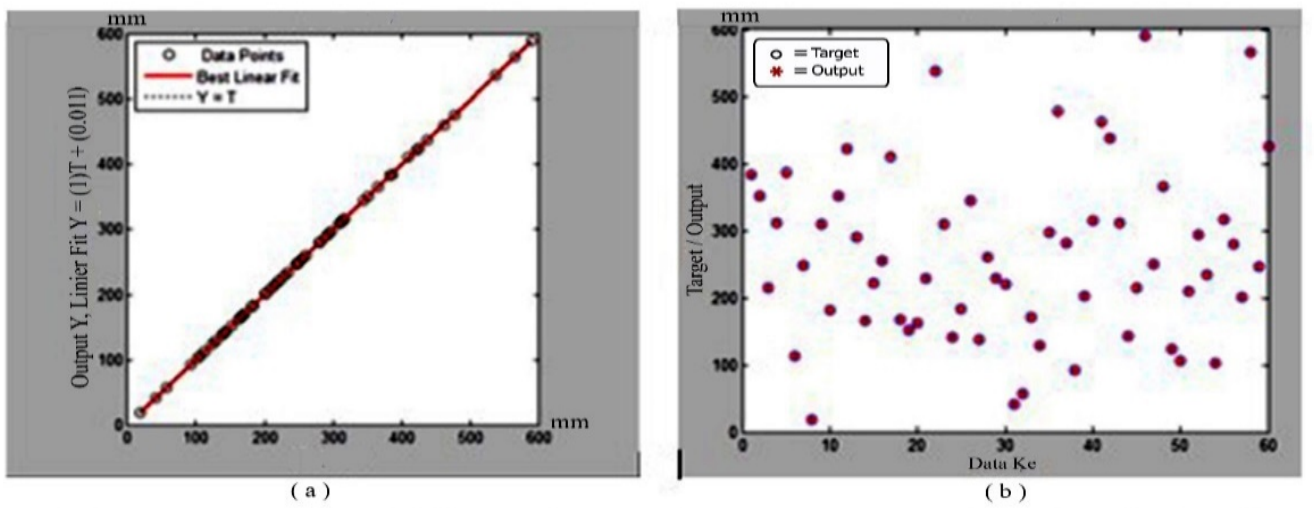

Gambar 1. (a) Hasil evaluasi pada data training (b) Hasil simulasi pada data training pada wilayah 3 $(153 ; 19,5)$ dengan R sebesar 1 dan nilai MSE minimal.

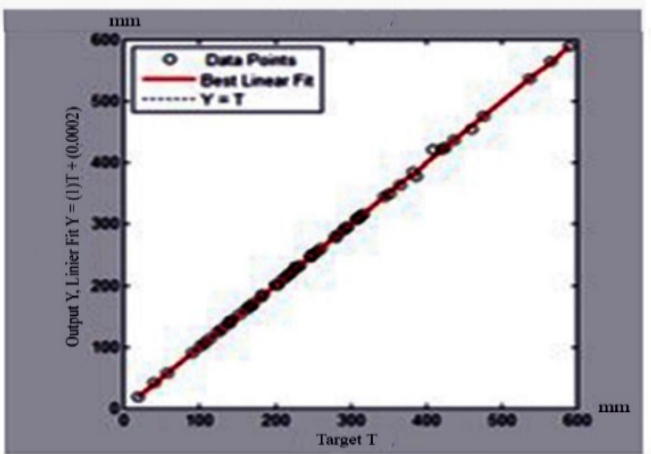

(a)

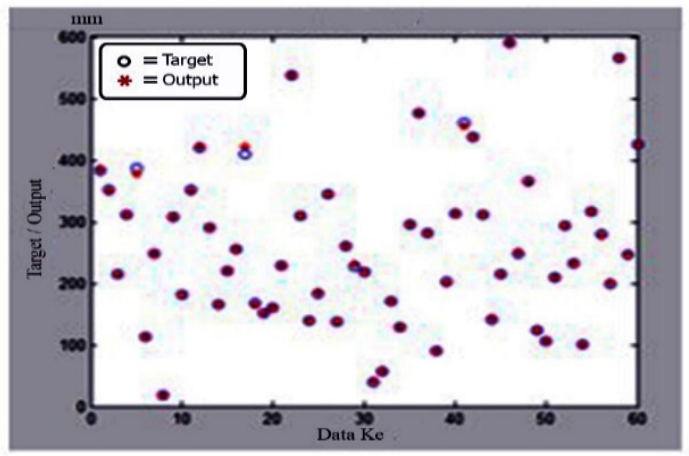

(b)

Gambar 2. (a) Hasil evaluasi pada data training (b) Hasil simulasi pada data Training pada wilayah 10 $(171 ; 1,5)$ dengan R sebesar 0.99 dan nilai MSE maksimal

Hasil evaluasi dan simulasi terlihat antara data training dan target telah bersesuaian berada di satu garis linear dan titik yang sama (Gambar 1 dan 2).

\section{b. Proses testing dan validasi pada JST}

Tabel 2. Hasil Proses Testing

\begin{tabular}{cccc}
\hline No & $\begin{array}{c}\text { Koordinat } \\
\text { (Bujur; Lintang) }\end{array}$ & R & MSE \\
\hline 1 & $63 ; 19,5$ & 0,66 & $2,97 \mathrm{e}-06$ \\
2 & $117 ; 19,5$ & 0,67 & $9,68 \mathrm{e}-06$ \\
3 & $135 ; 19,5$ & 0,62 & $1,26 \mathrm{e}-13$ \\
4 & $153 ; 19,5$ & 0,64 & $8,74 \mathrm{e}-07$ \\
5 & $171 ; 19,5$ & 0,61 & $3,11 \mathrm{e}-04$ \\
6 & $45 ; 1,5$ & 0,63 & $2,93 \mathrm{e}-04$ \\
7 & $63 ; 1,5$ & 0,71 & $1,33 \mathrm{e}-04$ \\
8 & $81 ; 1,5$ & 0,75 & $4,46 \mathrm{e}-06$ \\
9 & $153 ; 1,5$ & 0,70 & $6,03 \mathrm{e}-05$ \\
10 & $171 ; 1,5$ & 0,63 & $3,14 \mathrm{e}-04$ \\
11 & $63 ;-16,5$ & 0,66 & $2,97 \mathrm{e}-06$ \\
12 & $81 ;-16,5$ & 0,64 & $1,90 \mathrm{e}-09$ \\
13 & $99 ;-16,5$ & 0,66 & $9,72 \mathrm{e}-07$ \\
14 & $117 ;-16,5$ & 0,62 & $3,29 \mathrm{e}-06$ \\
15 & $153 ;-16,5$ & 0,64 & $1,75 \mathrm{e}-04$ \\
16 & $171 ;-16,5$ & 0,61 & $1,72 \mathrm{e}-09$ \\
\hline
\end{tabular}

Pada Tabel 2 di atas dapat dilihat bahwa nilai korelasi pada data baru yang dijadikan sebagai data uji proses testing memiliki korelasi yang lebih kecil daripada korelasi pada proses training. Terdapat tiga wilayah yang memiliki koefisien korelasi lebih tinggi dari 0,70. Adapun wilayah tersebut adalah; wilayah $7(63 ; 1,5)$ dengan nilai MSE sebesar 1,33e-04 memiliki korelasi sebesar 0,71 , di wilayah $8(81 ; 1,5)$ dengan nilai MSE sebesar 4,46e 04 terdapat koefisien korelasi sebesar 0,75 dan di wilayah 9 $(153 ; 1,5)$ dengan nilai MSE sebesar 6,03e-05 terdapat koefisien korelasi sebesar 0,70 ketigatiganya berada di garis equator. Wilayah 7 dan 8 terletak di sekitar garis equator di perairan samudera Hindia, sedangkan wilayah 9 berada di sekitar garis equator di perairan samudera Pasifik. Karena ketiga wilayah tersebut berada di sekitar garis equator maka pola SPL bulanan mengikuti pola equatorial sehingga korelasinya dengan curah hujan di kota Pontianak lebih tinggi dibandingkan dengan daerah lain.

Proses testing pada JST bertujuan untuk melihat apakah JST telah mampu mengenali pola input data baru yang telah diberikan. 


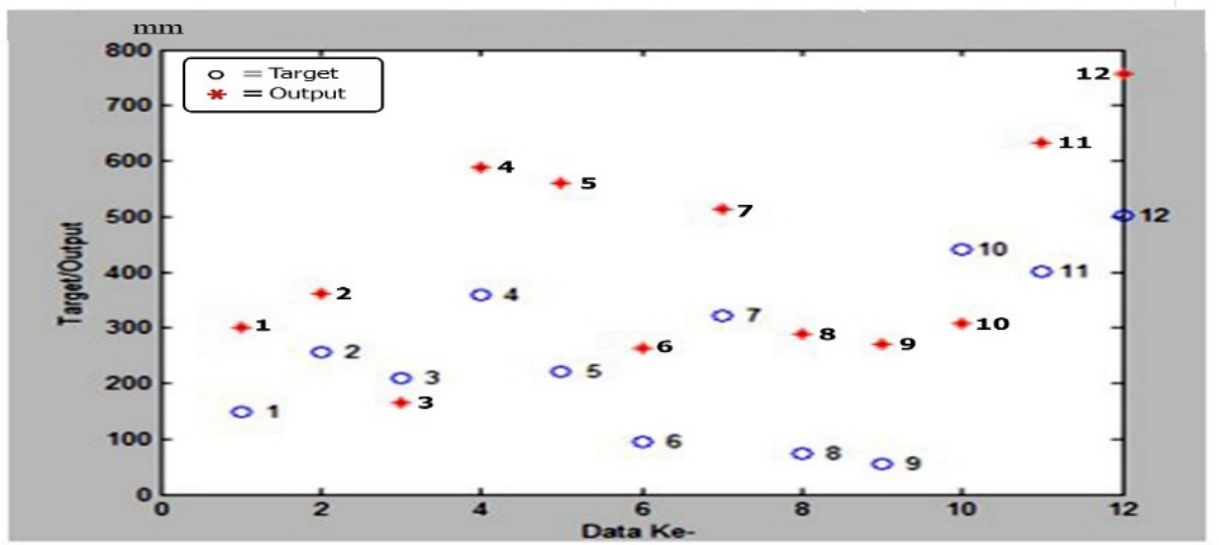

Gambar 3. Hasil simulasi pada data testing wilayah $7(63 ; 1,5)$ dengan R sebesar 0,71

Pada Gambar 3 di atas terlihat hasil dari proses Testing pada jaringan dengan input data baru yang diberikan. Pada gambar tersebut terlihat bahwa nilai output $(*)$ jaringan tidak semuanya mendekati nilai target (o) yang ada. Korelasi antara output $(*)$ dan target (o) menunjukkan hubungannya pada kategori kuat. Namun untuk hasil terbaik terjadi jika posisi output $(*)$ dan target (o) berada pada posisi yang sama.

Dari ketiga wilayah yang memiliki korelasi kuat tersebut di atas, memiliki nilai RMSE sebesar 545 di wilayah SPL 7, 591 di wilayah SPL 8 dan 550 di wilayah SPL 9.

\section{Kesimpulan}

Hasil simulasi JST pada arsitektur [15 10 5 10 di 16 wilayah SPL memiliki koefisien korelasi 0,99 s.d 1,00 diproses training.

Pada proses testing diperoleh 3 wilayah yang mempunyai korelasi kategori kuat dengan koefisien korelasi di atas 0,70. Ketiga wilayah tersebut berada di garis Khatulistiwa (equator). 2 wilayah berada di Samudera Hindia dan 1 wilayah berada di Samudera Pasifik. Hasil tersebut di atas menunjukkan bahwa nilai SPL dapat dijadikan sebagai estimator dalam mengestimasi curah hujan.

\section{Pustaka}

Desiani, A dan Arhami, M. 2005. Konsep Kecerdasan Buatan. ANDI, Yogyakarta.

Djunarsjah. 2005. Sifat-Sifat Fisik Air Laut, Hidrografi II, sudomogis.comTulisanHidrografi_SifatFisikAirLa ut.pdf, 6 Juni 2013.

Siang, JJ. 2004. Jaringan Syaraf Tiruan dan Pemogramannya menggunakan Matlab. Andi, Yogyakarta

Tukidi, 2010. Karakter Curah Hujan di Indonesia, Jurusan Geografi FIS UNNES, Semarang, http:/ / jurnal.unnes.ac.id/ index.php/ JG/ a rticle/ view/ 84, 15 April 2013. 